\title{
PREDICTION OF NUSSELT NUMBER OF RECTANGULAR FINS USING ARTIFICIAL NEURAL NETWORK MODEL
}

Ece AYLI, Department of Mechanical Engineering, Cankaya University, Turkey,-eayli@cankaya.edu.tr

(D) https://orcid.org/0000-0002-6209-161X)

Received: 19.02.2019, Accepted: 09.07.2019

Research Article

*Corresponding author

DOI: $10.22531 /$ muglajsci.529193

\begin{abstract}
In the passive heat transfer enhancement methods, there are several parameters which need to be optimized to maximize the heat transfer coefficient and Nusselt number while minimizing the pressure drop. For this purpose, empirical correlations are generated by experimental and numerical studies. In this study, a heat transfer analysis of rectangular fins with experimental data by an artificial neural network approach is performed. Artificial Neural Network method is compared with the classical regression model. Different networks with a different number of neurons in the hidden layer and several training algorithms are tested for the defined problem. The results show that the ANN model is found faster and more accurate than conventional techniques if the optimum architecture is generated and convenient training algorithm is chosen for the specific problem. For this problem, 10-5-1 network with Bayesian Regularization training algorithm is selected as the best scenario with $7.6 \%$ mean absolute percentage error (MAPE) and 0.029 RMSE value while maximum MAPE value is reached to $56.3 \%$ with Levenberg-Marquardt training algorithm and with 10-12-1 network. Keywords: Artificial Neural Network, Heat Transfer, Nusselt Number, Overall Heat Transfer Coefficient
\end{abstract}

\section{YAPAY SİNİR AĞLARI İLE DİKDÖRTGEN FINLERİN NUSSELT SAYISI TAHMINLEMESİ}

\section{Özet}

Pasif ısı transferi iyileștirme metodlarında ısı transferi kat sayısı ve Nusselt sayısını maximize ederken, basınç düşümünü minimize eden yaklaşımı tespit edebilmek için bir çok parametrenin optimizasyonunun yapılması gerekmektedir. Bu sebepten ötürü, deneysel ve sayısal çalışmalara bağlı olarak ampirik korelasyonlar elde edilmektedir. Bu çalışmada dikdörtgensel finlerin ısı transferi davranışı deneysel ve yapay sinir ağları metodları ile ortaya konmuştur. Yapay sinir ağları metodolojisi ile elde edilen sonuçlar korelasyon ile klyaslanmıştır. Ayrıca, tanımlanan problem için yapay sinir ağı uygulamasında farklı eğitim algoritmalarının ve katman sayısının sonuçlar üzerindeki etkisi araştırılmıştır. Elde edilen sonuçlara göre YSA yöntemi, korelasyon yönteminden daha hızlı ve daha doğru sonuç vermektedir. Diğer yandan YSA yaklaşımının doğruluğunun arttırılması için uygun eğitim algoritmasının seçimi, uygun katman sayısının tespiti yani uygun mimarinin elde edilmesi önem arz etmektedir. Tanımlanan bu problem için, 10-5-1 ağına sahip Bayesian Regularization algoritması \%7.6 ortalama yüzde hata ve 0.029 RMSE ile iyi senaryo olarak belirlenmiștir. Maximum ortalama hata \%56.3 ile Levenberg-Marquardt algoritmasında 10-12-1 ă̆ı ile elde edilmiştir.

Anahtar Kelimeler: Yapay Sinir Ağları, Isı Transferi, Nusselt Sayısı, Isı Transferi Katsayısı

Cite

Ayli, E., (2019), "Predıctıon of Nusselt Number of Rectangular Fins Usıng Artıficıal Neural Network Model”, Mugla Journal of Science and Technology, 5(2), 13-22.

\section{Nomenclature}

C Specific Heat Capacity $\left[\mathrm{J} / \mathrm{kg}^{\circ} \mathrm{C}\right]$

d Inter-fin distance [m]

$\mathrm{D}_{\mathrm{h}} \quad$ Hydraulic diameter $[\mathrm{m}]$

$\mathrm{h} \quad$ Convection heat transfer coefficient $\left[\mathrm{W} / \mathrm{m}^{2}{ }^{\circ} \mathrm{C}\right]$

$\mathrm{k} \quad$ Thermal conductivity $\left[\mathrm{W} / \mathrm{m}^{\circ} \mathrm{C}\right]$

$\begin{array}{ll}\text { Subscripts } & \text { Density }\left[\mathrm{kg} / \mathrm{m}^{3}\right] \\ \mathrm{s} & \text { Thermocouple position } \\ \infty & \text { Free stream } \\ \mathrm{i} & \text { Processing element }\end{array}$




$\begin{array}{ll}\mathrm{L} & \text { Fin length }[\mathrm{m}] \\ \mathrm{rmse} & \text { Root-mean-square error } \\ \mathrm{R}^{2} & \text { Correlation Coefficient } \\ \mathrm{T} & \text { Fin thickness }[\mathrm{m}] \\ \mathrm{u} & \text { Velocity }[\mathrm{m} / \mathrm{s}] \\ \mu & \text { Viscosity }\left[\mathrm{Ns} / \mathrm{m}^{2}\right]\end{array}$

\section{Introduction}

Finned surfaces have been extensively used for enhancing heat transfer rates in many fields including electronic systems, heat exchangers, piping systems, chemical processing systems, and aircraft applications. Controlling and optimizing the heat transfer rates in the systems brings some advantages with it like saving supplied power, increasing efficiency, reducing the maintenance time, and increasing the lifetime. According to these objectives, finned surfaces are commonly used to enhance heat transfer. Especially, rectangular fins are commonly used due to their simplicity in manufacturing and low prices [1-3].

Since the 1960's heat transfer enhancement techniques with finned surfaces are under investigation and still need development, in the several industrial application areas, cooling is still a crucial problem. When the fin parameters (fin location, fin number, fin width, fin height, fin separation distance...) are not optimized accurately, instead of increasing the heat transfer rates fin surfaces can resist and block the incoming air flow which will affect heat transfer rate adversely [4].

To inhibit such problems and to provide effective heat transfer to the systems, it is necessary to understand the nature of the flow and crucial to investigate the effect of heat transfer characteristics of the flow with finned surfaces. Creating modification in the finned surfaces is the most popular way to enhance heat transfer. In the literature, there are several types of research that predict the performance of finned surfaces using empirical heat transfer correlations based on "least squares" analysis of experimental and numerical data. Tan et al. [5] revealed that, if the thermal and transport properties of the system cannot be predicted properly in the experiments or the numerical analysis, this method does not provide accurate results. In sight of this situation, artificial neural networks (ANN) can be a more efficient alternative when it is compared with classical correlations.

Turk et al. [6], compared the artificial neural network to classical correlation method by using the mixed-plate gasketed plate heat exchanger experiment results. Due to their results, the ANN approach gives more accurate results than experimental correlations to predict the friction factor and Nusselt number distribution.

$\begin{array}{ll}\mathrm{j} & \text { hidden layer number } \\ \text { Superscripts } & \\ \mathrm{p} & \text { Predicted } \\ \mathrm{e} & \text { experimental }\end{array}$

Tan et al. [5] examined the performance of compact heat exchanger with the ANN method. They utilized a MultiLayer Feed-Forward (MLFF) ANN with a tan-sigmoid transfer function to the experimental data set. They optimized the number of neurons in the hidden layer to maximize the performance of the network. They claimed that, designed ANN architecture predictions are more compromising with experimental data than a non-linear regression model.

Islamoglu et al. [7,8], experimentally studied the Nusselt number distribution for air flowing corrugated channel, and they tested the accuracy of the ANN method for this engineering problem. The ANN architecture that they used has four input and one output layer. Hidden layer number varies between 1 to 15 to observe the effect of the hidden layer number to the ANN performance. For this problem, the 4-5-1 ANN configuration is found to have the best performance. In other another study, they used the ANN approach for predicting the performance of non-adiabatic capillary tube suction line heat exchanger. Their results showed that to predict the mass flow rate and an outlet temperature of such a problem, ANN can be used trustingly.

Xie et al. [9] predicted the performance of heat exchangers with different fin patterns by the use of artificial neural networks. Due to their various network configurations, best results are obtained with 12-9-5-2 architecture. In their other study, they set a shell-andtube experimental system to perform ANN to the experimental data. They used a back-propagation algorithm with eight inputs and two outputs [10]. They concluded both studies by revealing that although ANN cannot simulate the unknown physical phenomena directly, it is very suitable in the prediction of heat transfer performance.

Using the three-dimensional numerical data Chen et al [11] developed an ANN model to predict the performance of a heat exchanger (HEX). They used different training algorithms and they showed that LM algorithm is the most feasible option for their problem and they observed that when hidden layer neuron number is raised to a number higher than 10 , relative mean error values increase.

Shojaeefard et al. [12] utilized the ANN method to predict the performance of an air-to-refrigerant laminated type evaporator. Their observation is that recurrent neural 
network can be proposed as an alternative method for performance prediction of heat exchangers.

In the previous study of the author $[13,14]$, steady-state heat transfer from rectangular fin arrays is examined experimentally and a Nusselt number correlation is presented for steady state turbulent forced convection regimes. In this paper, an alternative approach based on artificial neural network model is presented to investigate the effect of rectangular fin geometrical parameters on heat transfer coefficient and Nusselt number. In the study, different network configurations and different training methodologies are tried to find the optimum ANN architecture for this problem. In addition to that, predicted results coming from optimum ANN network is compared with the correlation that is presented in the previous study.

\section{Materials And Methods}

\subsection{Experimental Setup and Measurements}

Experiments are performed in the Middle East Technical University Heat Transfer Laboratory in order to investigate the effects of fin length, inter-fin distance effect to the heat transfer. The details of the test set up are given in Ayli et. al. $[13,14]$. The schematic view of the set-up is depicted in Figure 1. The aluminum test-section has a $225 \mathrm{~cm} 2$ cross section with $400 \mathrm{~mm}$ width (W) and $150 \mathrm{~mm}$ length (L). A high-pressure blower fan is used to supply air to the test channel. Anemometer is mounted to the duct to measure the velocity values of the working fluid. To obtain a uniform flow field, converging diverging inlet and honeycomb are used.

To achieve constant heat flux, an electrical heater plate is used with a voltage adjuster. Heat loss to the ambient is minimized by the use of insulation material through the test channel.

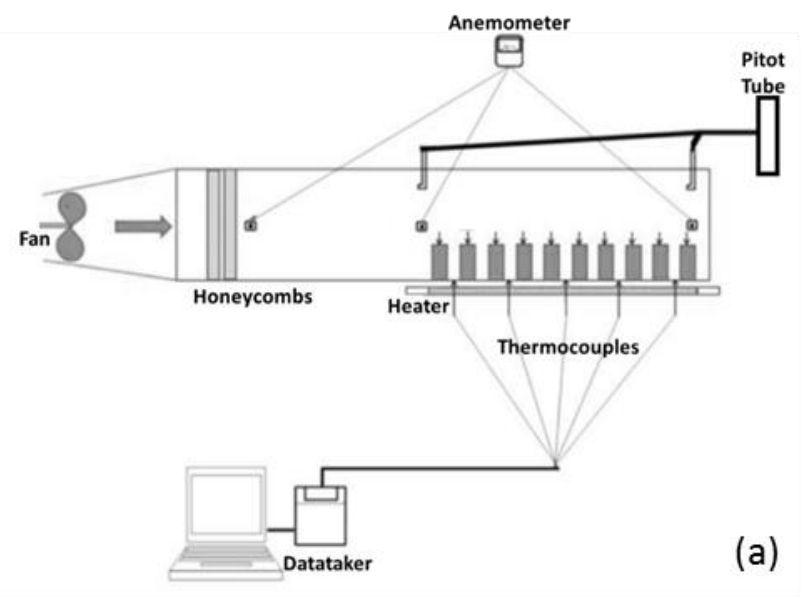

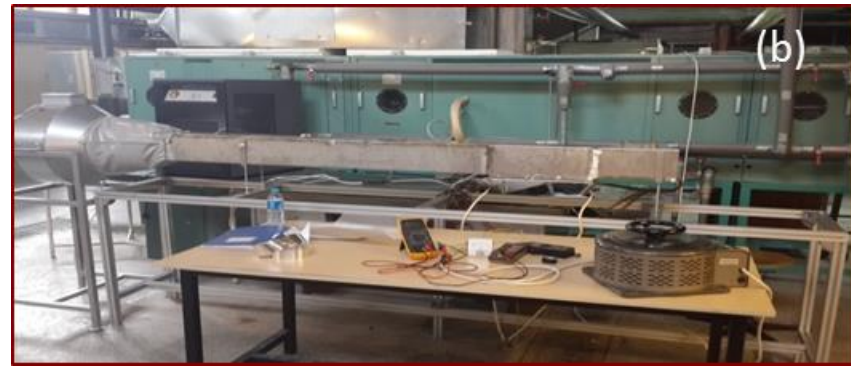

Fig. 1. (a) View of experimental set-up schematically

(b) Pictorial view of the experimental set-up

The entrance, the exit, and the finned surface temperature values are measured by using 36 thermocouples calibrated with in $\pm 0.3^{\circ} \mathrm{C}$, and all temperature values are read through a data acquisition system. The uncertainty of the measurements is shown in Table 1.

Table 1. Uncertainty of the measurements

\begin{tabular}{lc}
\hline \multicolumn{1}{c}{ Instruments } & Uncertainty \\
\hline $\begin{array}{l}\text { The voltage supplied by power source, } \\
\text { voltage }\end{array}$ & $\pm 0.02 \%$ \\
The voltage supplied by power source & $\pm 0.02 \%$ \\
ampere & \\
Thermocouple type T & $\pm 0.3 \%$ \\
Differential Pressure Transducer & $\pm 0.02 \%$ \\
\hline
\end{tabular}

Based on the Coleman and Steele [15], the uncertainties of the relevant parameters obtained from the data reduction process are calculated, and their values are $7.2 \%$ and $0.9 \%$ for Nusselt number and heat transfer coefficient respectively. For several cases temperature distribution through the test section is shown in Figure 2.

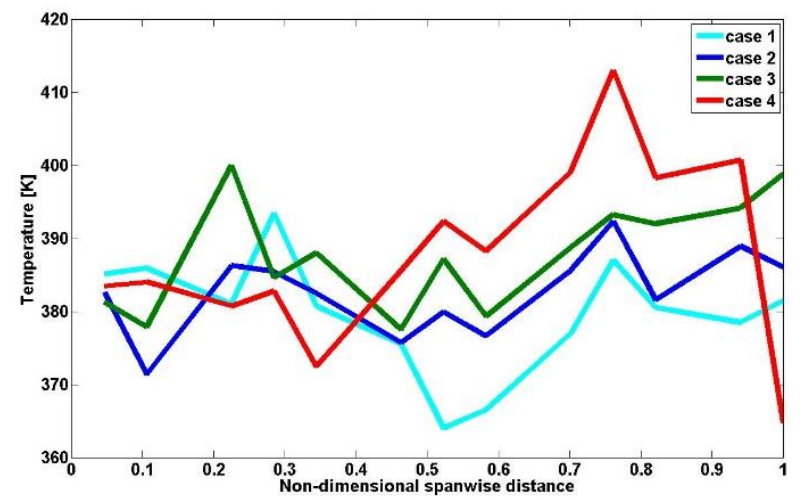

Fig 2. Temperature distribution for several cases

From the measured air velocities, the Reynolds number is calculated based on the hydraulic diameter definition of Munson [15] as it is given in Equation (1). 


$$
\operatorname{Re}=\frac{\rho u D_{h}}{\mu}
$$

Where $\mathrm{u}$ is the free stream velocity, ? ?is the dynamic viscosity, ? ? is the density of the air and $D_{h}$ is the hydraulic diameter. From the temperature data that comes from the data acquisition system, which are measured with the help of the thermocouples, thermophysical properties of the air are calculated for each temperature value at each time step [17]. Using the thermophysical properties, Prandtl number is calculated using the following formula:

$$
\operatorname{Pr}=\frac{C_{p} \mu}{k}
$$

Where $C_{p}$ and $k$ are the specific heat and thermal diffusivity, respectively. Net heat transfer rate is calculated by using the energy balance that is given in Eq. (3). In the equation, $Q_{\text {net }}$ is the total power input, $Q_{\text {vol }}$ is calculated with Ohms Law, and Qloss is the heat loss through the insulation which is dependent to insulation thermal conductivity, insulation area, and temperature difference through the insulation.

$$
Q_{\text {net }}=Q_{\text {vol }}-Q_{\text {loss }}
$$

From the connective heat transfer formula, heat transfer coefficient $(\mathrm{h})$ is measured at each thermocouple position.

$$
h=\frac{q_{\text {test piece }}^{\prime \prime}}{\left(T_{s}-T_{\infty}\right)}
$$

Where $\mathrm{T}_{\mathrm{s}}$ is the temperature value at each thermocouple position, $\mathrm{T}_{\infty}$ is the free stream temperature. Nusselt number is calculated using the heat transfer coefficient, hydraulic diameter, and thermal conductivity value for each point.

$$
N u=\frac{h D_{h}}{k}
$$

The geometric parameters of aluminum finned test pieces are given in Table 2 . In the table, $d$ and $t$ denote the inter-fin distance and fin thickness respectively.

Table 2. Geometrical Fin Parameters

\begin{tabular}{cccc}
\hline $\begin{array}{c}\text { Test } \\
\text { Cases }\end{array}$ & $\begin{array}{c}\text { Number } \\
\text { of Fins }\end{array}$ & $\mathbf{d} / \mathbf{w}$ & $\mathbf{t} / \mathbf{L}$ \\
\hline $\mathbf{1}$ & 8 & 0,089 & 0,248 \\
$\mathbf{2}$ & 8 & 0,089 & 0,284 \\
$\mathbf{3}$ & 8 & 0,089 & 0,331 \\
$\mathbf{4}$ & 8 & 0,089 & 0,398 \\
$\mathbf{5}$ & 8 & 0,062 & 0,546 \\
$\mathbf{6}$ & 8 & 0,062 & 0,624 \\
\hline
\end{tabular}

\begin{tabular}{llll}
\hline $\mathbf{7}$ & 8 & 0,062 & 0,729 \\
$\mathbf{8}$ & 8 & 0,062 & 0,028 \\
$\mathbf{9}$ & 8 & 0,034 & 0,034 \\
\hline
\end{tabular}

Using the data obtained with the calculation methodology, correlation is obtained using the experimental data. The detail about the development of Nusselt number correlation is given in the previous study [13]. Different regression models were tested at test boundaries (lower \& upper limits) using the data set. To verify the obtained correlation, a verification set is prepared by utilizing the data which is not included in the regression data set. Until reaching the minimum root mean square error (RMSE) that provides close enough values to the experimental results, different regression models are tried. In Figure 2, the correlation development methodology is given. The correlation which is obtained with using least square regression model and the range that correlation is applicable is given in $\mathrm{Eq}(6)$.

$$
\begin{gathered}
N u=4.69822 \times 10^{-7} \operatorname{Re}^{1.11986}\left(\frac{d}{w}\right)^{-0.2151597}\left(\frac{t}{L}\right)^{-0.2079137} \\
{\left[\begin{array}{l}
9.17 \times 10^{7}<\operatorname{Re}<2.47 \times 10^{8} \\
0.089<\frac{d}{w}<0.0625 \\
0.2485<\frac{t}{L}<0.729
\end{array}\right]}
\end{gathered}
$$

\subsection{Artificial Neural Network}

Artificial Neural Networks comprises a great number of neurons that aliens in sequential order, which is used for prediction purposes. Such a network consists of a series of layers with several nodes. Those nodes are named as neurons which are the processors of the ANNs. The connections between two neurons are called weight which has numerical values. The column that neurons formed is known as layers where the first layer is the input layer whereas the last layer is the output layer. The layers between the input and output layer are called hidden layers. Some hidden layers can change because of the network. This is one of the parameters that should be optimized to reach the maximum accuracy level with ANN methodology. Each neuron in each layer is connected to all the neurons in the following layer. Neuron number in the hidden layer also needed to be optimized in order to reach accurate results. As shown in Figure 3, the first layer with three neurons is the input layer, the last layer with one output is the output layer and the layer between them is the hidden layer with five 
neurons.

In this paper such an ANN network is depicted as 3-5-1 and in the optimization procedure of the ANN architecture five different networks are constituted for three different algorithms. In conclusion 15 different ANN architectures are tested in order to find minimum RMSEE.

As shown by Elmas [18], sometimes increasing the hidden layer number can increase the errors and can lead to secession from the desired results. Therefore; network preparation, training algorithm, network architecture (number of layers and number of the neurons...) needs an optimization process as well as know-how [19]. Moreover, as Gang et al. [20] have studied; ANN is a datadriven, self-adaptive model which is a universal functional approximator.

The output parameter which is Nusselt Number for this problem is predicted by using different training algorithms. Speed and accuracy level of the training algorithms are dependent on several parameters like the complexity of the problem, the number of data points in the training set, the number of weights and biases in the network. In the user guide of the Matlab [20] various training algorithms are compared for different problems. The results show, Levenberg-Marquardt (LM) algorithm is suitable for the problems in which the network has fewer than one hundred weights. However in a problem with 30 hidden layer networks LM method is not suitable, the SCG method gives better accuracy levels and it is appropriate for function approximation problems. In sight of these examples, it is seen that for such a heat transfer problem finding the optimum training algorithm is obligatory. Therefore, three different training algorithms (Levenberg-Marquardt, Bayesian Regularization (BR) and Scaled Conjugate Gradient (SCG) are tried in all of the ANN architectures.

In the hidden layer tan-sigmoid transfer function and the outline layer pureline function are used which are the most commonly used functions for multilayer networks [21]. The output value is predicted using Multilayer Perceptrons (MLP) feed-forward neural networks trained by the backpropagation algorithm. In the network using the input data $\mathrm{x}_{\mathrm{i}}$, hidden layer

number $j$, weight of the biases between layers $w_{i j}$ data developed in the boundaries is calculated as given in Eq (7).

$$
S_{i}=\sum_{i=1}^{n} w_{i j} x_{i}+\theta_{j}
$$




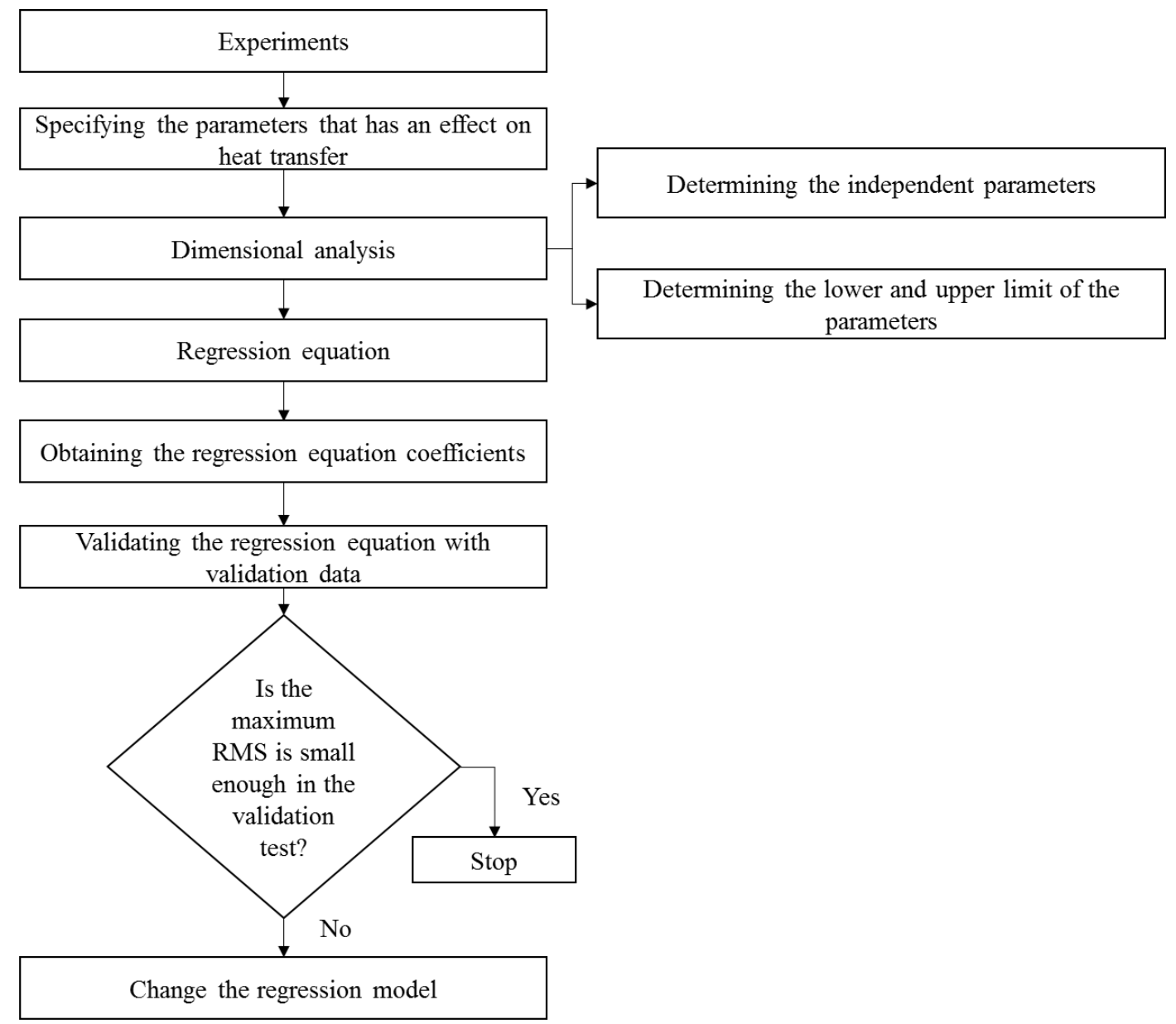

Fig. 2. Development of correlation methodology

This data used in the transfer function, which is chosen as a sigmoid function for this problem, which is given in Eq (8):

$$
f\left(S_{i}\right)=\frac{1}{1+e^{-\beta\left(S_{i}\right)}}
$$

Where $S_{i}$ is the weighted sum of the input, $w_{i j}$ is the weights of the connection between the $i^{\text {th }}$ and $j^{\text {th }}$ processing elements. $X_{j}$ is the output $j^{\text {th }}$ processing element, and $S_{j}$ is the weighed of the biases between the layers.

In all of the cases, convergence criteria are chosen as 104 , if it does not reach to the convergence criteria program performance 35000 epochs. For all of the designed networks, ten different parameters were fed into the input, which has a direct effect on heat transfer, and output is chosen as Nusselt number.

For nine different cases and with the use of 30 thermocouple data for each experiment, 270 data are used in the ANN method. 270 data are randomly divided into two groups: $85 \%$ (230 data) are used as training data, and $15 \%$ (40 data) are used for testing data. As a model performance evaluation criterion: root mean square root (RMSE), Max Relative Error, R, Correlation Coefficient and $\sigma$ values are calculated as shown in Eq (9) to $\mathrm{Eq}(13)$.

$$
\begin{array}{r}
A P E=\frac{\left|R^{e}-R^{p}\right|}{R^{e}} \times 100 \% \\
R M S E=\sqrt{\frac{1}{N} \sum_{i=1}^{N}\left(\frac{R^{e}-R^{p}}{R^{e}}\right)^{2}}
\end{array}
$$

In equation 9, which is absolute Absolute Percentage Error, $\mathrm{R}^{\mathrm{e}}$ is the experimental result, $\mathrm{R}^{\mathrm{p}}$ is the predicted result. In all of the trials maximum, $\mathrm{R}^{\mathrm{e}}$ value is taken from 270 data points to find the maximum relative error. In Equation (10), $\mathrm{N}$ is the number of data sets of data for training of the network

$$
R=\frac{1}{N} \sum_{i=1}^{N} R_{i}=\frac{1}{N} \sum_{i=1}^{N} \frac{R^{e}}{R^{p}}
$$




$$
\begin{gathered}
\sigma=\sqrt{\frac{1}{N} \sum_{i=1}^{N}\left(\frac{R-R_{i}}{N}\right)^{2}} \\
R^{2}=1-\frac{\sum_{i=1}^{N}\left(R_{i}^{e}-R_{i}^{p}\right)^{2}}{\sum_{i=1}^{N}\left(R_{i}^{e}\right)^{2}}
\end{gathered}
$$

In Equation 11, $\mathrm{R}$ values calculate the correlation between target and output. To reach the close relationship $R$ values should be near to 1 . When $R$ is equal to 0 , this situation corresponds to a random relationship. In Equation 12, $\sigma$ value is the average squared difference between outputs and targets where lower values correspond to better design and zero means no error in the trained algorithm.

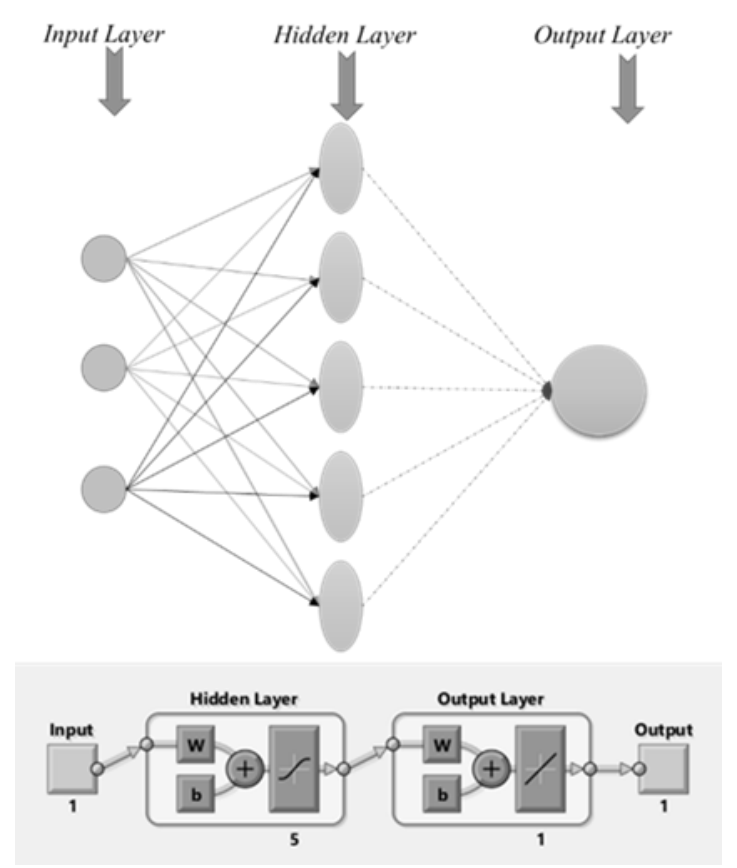

Fig. 3. Schematically view of 3-5-1 ANN system Architecture

\section{Results \& Discussion}

Experiments are performed in order to maximize the heat transfer rate of the system using finned surfaces with optimized geometrical structures. As seen in the combined experimental and numerical study, results indicate that increasing the inter-fin distance, and Reynolds number has a positive impact on Nusselt number distribution. On the other hand, increasing the clearance ratio $(\mathrm{C} / \mathrm{L})$ has an adverse impact on the Nusselt number.

Detailed graphics are given in the previous study of the author [13]. In this study modeling of ANN is performed under the MATLAB 2014a environment. In Table 3, network architectures and training algorithms that are tried in order to minimize the RMSE and MRE are given and error comparison is performed for all of the cases. $\mathrm{R}$ and sigma values are the most important criteria for ANN success [22]. As it is seen in Figure 4, with increasing the hidden neurons , $R$ values come closer to unity for all of the training algorithms. Although R behavior for different algorithms is similar to each other relative errors (Figure 4(b)) are not the same. Especially for the LM algorithm, increasing the neuron number in hidden layer does not provide better predictions. For BR and SCG algorithm after seven neurons, increasing the neuron number lost its dominant influence on $\mathrm{RE}$ and $\mathrm{R}$ values.
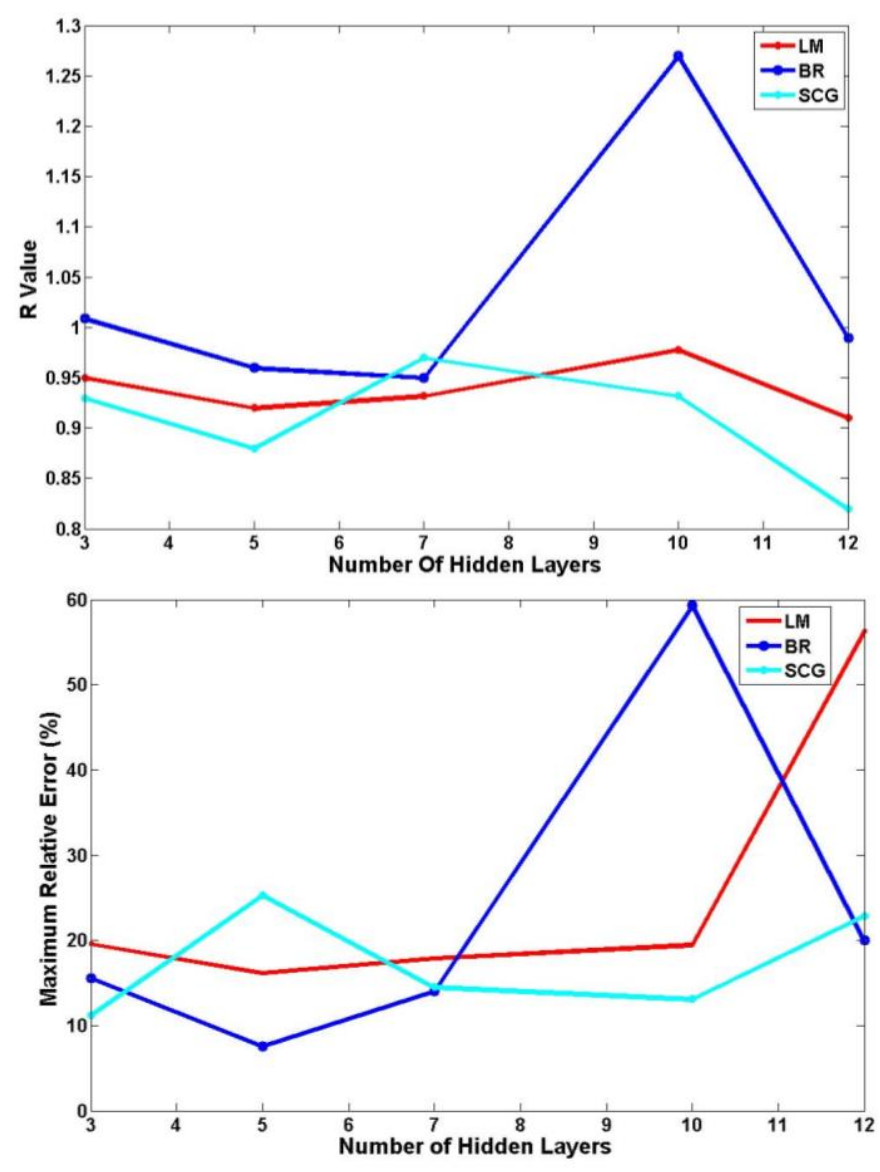

Fig. 4.(a)Comparison of R values (b) Relative Errors for different training algorithms

When Table 2 and Figure 4 is examined together, for this case 10-5-1 network with BR training algorithm is selected as the best scenario. Scattering of the prediction values which is depicted with $\sigma$ in Eq (12) also close to zero which means that error is minimized with this architecture and algorithm. Also, it is observed that for this problem, SCG and BR algorithms are better approaches than the LM algorithm. When $\mathrm{R}$ values are 
examined, BR algorithm gives much closer to unity $\mathrm{R}$ values when compared to the two other models. Figure 5 shows the relative percentage errors for some random data points for ANN and correlation prediction for 10-51 network with BR algorithm. In the correlation, maximum error reaches $25 \%$, whereas in the ANN maximum error is in a level of $10 \%$. In Figure 6, correlation Nusselt number values are compared with ANN Nusselt numbers. It is clear that the ANN method is in greater agreement with experimental values than conventional regression equation for such a heat transfer problem.

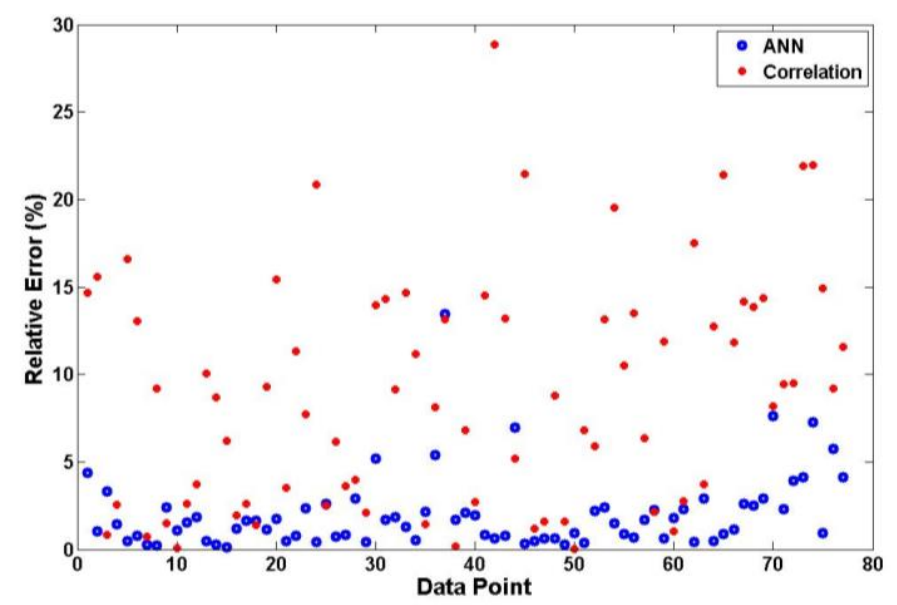

Fig 5. Relative Error for 10-5-1 configuration with BR training algorithm (for training data set)

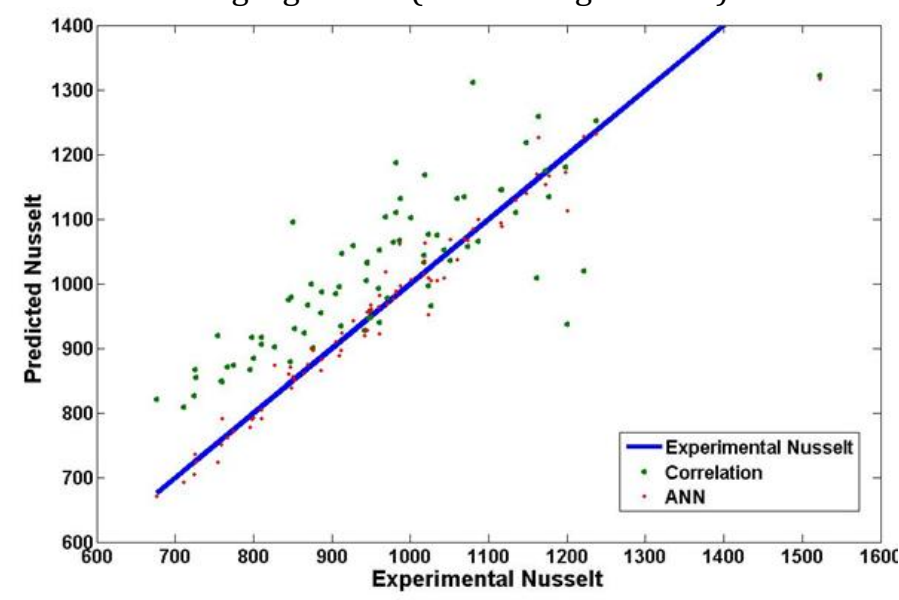

Fig.6 Comparison of correlation and ANN (10-5-1/BR) obtained from experiments

The regression curve is shown in Figure 7, using the test data for the Nusselt number. In the most appropriate training algorithm and method, $\mathrm{R}^{2}$ is calculated as 0.99989 .

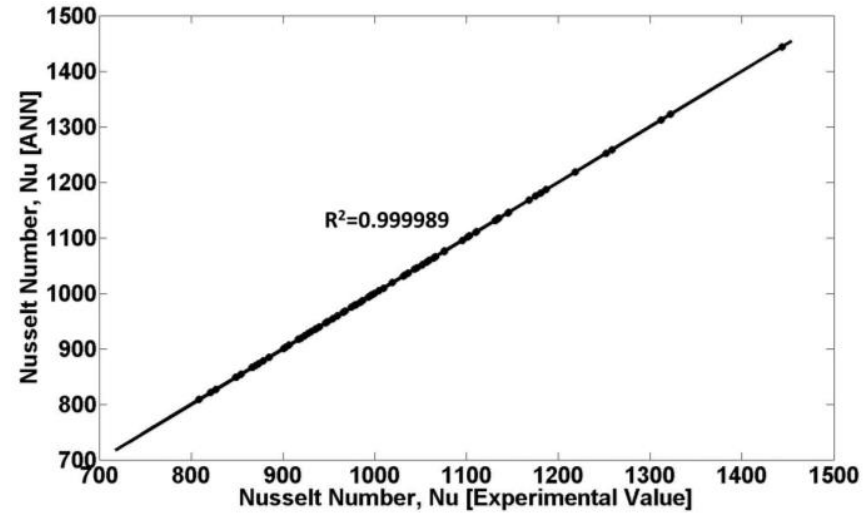

Fig 7. Comparison of experimental and ANN-predicted values (10-5-1/BR) of Nusselt number for the test data

In Figure 8, Nusselt number distribution versus Reynolds number for experimental, correlation, and ANN data is shown. ANN data is obtained with using 10-5-1 network with BR algorithm. The maximum relative error between experiment and correlation is $11.2 \%$ while the maximum relative error between experiment and ANN result is $4.57 \%$.

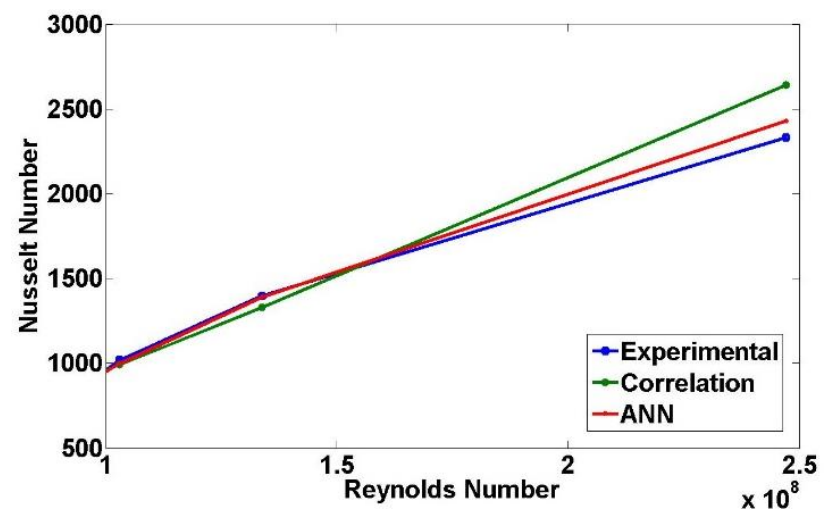

Fig. 8. Comparison of experimental results with correlation and ANN results for case 1

\section{Conclusion}

In this research paper, the ANN method is compared with the conventional regression model. To find the most appropriate ANN architecture, several ANN models are established and tested with three different training algorithms. Highlights of the study are given below:

- It is presented that ANN yields superior prediction than the classical correlation for such a heat transfer enhancement problem. In the correlation, maximum error reaches $25 \%$, whereas in the ANN maximum error is at a level of $10 \%$.

- Increasing the number of neurons not always increases the accuracy of the model and can sometimes cause overtraining problems. Therefore, one of the important parameters that should be optimized is the number of neurons in the hidden layer to reach the unity in $\mathrm{R}$ and to degrade the RMSE. 
- $\quad$ Training algorithms have a direct effect on the ANN results. For this heat transfer problem, which has six inputs; BR algorithm gives the best approach.

- It is not possible to obtain a single correlation that represents all the fin geometries in a wide range, on the other hand, when ANN's are used, it is easier to predict the performance of fin configuration.

- With more experimental data in a wider range of parameters the performance of the ANN model could also be improved

- $\quad$ As a further study of this problem, the ANFIS estimation method can be compared with the ANN method.

Table 3. Error Comparison based on Nusselt number predictions by different training algorithms

\begin{tabular}{l|l|l|l|l}
\hline \multicolumn{1}{c|}{ Network } & \multicolumn{2}{|c|}{ Training Data Set } & \multicolumn{1}{c}{ Test Data Set } & Training Algorithm \\
\hline & $\begin{array}{c}\text { Max } \\
\text { Relative } \\
\text { Error (\%) }\end{array}$ & RMSE & \multicolumn{1}{c}{$\mathrm{R}^{2}$} & \\
\hline \hline $10-12-1$ & 56,3000 & 0,1400 & 0.99762 & Levenberg-Marquardt \\
\hline $10-10-1$ & 19,5000 & 0,0400 & 0.99971 & Levenberg-Marquardt \\
\hline $10-7-1$ & 17,9000 & 0,0540 & 0.99001 & Levenberg-Marquardt \\
\hline $10-5-1$ & 16,2000 & 0,0340 & 0.98969 & Levenberg-Marquardt \\
\hline $10-3-1$ & 19,6000 & 0,0470 & 0.98999 & Levenberg-Marquardt \\
\hline \hline $10-12-1$ & 20,0000 & 0,0300 & 0.99786 & Bayesian Regularization \\
\hline $10-10-1$ & 59,3000 & 0,1900 & 0.89997 & Bayesian Regularization \\
\hline $10-7-1$ & 14,0700 & 0,0190 & 0.99996 & Bayesian Regularization \\
\hline $10-5-1$ & 7,6000 & 0,0290 & 0.99997 & Bayesian Regularization \\
\hline $10-3-1$ & 15,6000 & 0,0400 & 0.99989 & Bayesian Regularization \\
\hline $10-12-1$ & 22,9000 & 0,1100 & 0.99456 & Scaled Conjugate Gradient \\
\hline $10-10-1$ & 13,1000 & 0,0520 & 0.89623 & Scaled Conjugate Gradient \\
\hline $10-7-1$ & 14,5000 & 0,0300 & 0.99997 & Scaled Conjugate Gradient \\
\hline $10-5-1$ & 25,3000 & 0,0470 & 0.99992 & Scaled Conjugate Gradient \\
\hline $10-3-1$ & 11,2000 & 0,0450 & 0.99975 & Scaled Conjugate Gradient \\
\hline
\end{tabular}

\section{Acknowledgments}

The construction of the set-up is financially supported by METU-BAP project (BAP-08-11-2013-035) and the experiments were performed at METU Department of Mechanical Engineering HeatTransfer Laboratory.

The author would like to thank to Dr. Ozgur Bayer and Prof. Dr. Selin Aradag for their support and assistance.

\section{REFERENCES}

[1] Sheikholeslami,M., Bandpy, M.G., Ganji,D.D., "Review of heat transfer enhancement methods: Focus on passive methods using swirl flow devices", Renewable and Sustainable Energy Reviews, Vol:49, pp:444-649.,2015.

[2] Kraus, A., Azız,A.B., Welty, J. Extended Surface Heat Transfer, John Wiley \&Sons, USA,2011

[3] Jeng, T.M.,Tzeng,. S.C, "Pressure Drop and Heat Transfer of Square Pin-Fin Arrays in in-Line and Staggered Arrangements", International Journal of Heat and Mass Transfer, vol:50, pp: 2364-2375,2007.

[4] Starner, K.E. ve McManus, Jr H.N., "An Experimental Investigation of Free Convection Heat Transfer From Rectangular Fin Arrays", Journal of Heat Transfer, vol:85 pp:273-278,1963.

[5]Tan, C.K.,Ward,J., Wilcox, S.J.,Payne, R. "Artificial Neural Network Modelling of the Performance of a Compact Heat Exchanger" , Applied Thermal Engineering, vol: 29, pp:3609-3617,2009.

[6] Turk, C., Aradag, S., Kakac, S., “ Experimental Analysis of a Mixed-Plate Gasketed Plate Heat Exchanger And Artificial Neural Net Estimations Of The Performance As An Alternative To Classical Correlations", International Journal of Thermal Sciences, vol:109, pp: 263-269,2016.

[7 ] Islamoglu, Y. ve Kurt,A, "Heat Transfer Analysis Using ANNs with Experimental Data for Air Flowing in Corrugated Channels", International Journal of Heat and Mass Transfer, vol: 47, pp:1361-1365,2004.

[8] Islamoglu, Y., Kurt, A. Parmaksızoğlu, A., "Performance Prediction for non-adiabatic Capillary Tube Suction Line Heat Exchanger: An Artificial Neural 
Network Approach", Energy Conversion and Management, vol:46,pp: 223-232,2005.

[9] Xie,G., Sunden, G., Wang, Q., Tang,L., "Performance Predictions of Laminar and Turbulent Heat Transfer and Fluid Flow of Heat Exchangers Having Large TubeDiameter and Large Tube-Row by Artificial Neural Networks", International Journal of Heat and Mass Transfer, vol:52,pp: 2484-2497,2009.

[10] Xie., G.N, Wang, Q.W., Zeng, M., Loo, L.Q., "Heat Transfer Analysis for Shell-and- Tube Heat Exchangers with Experimental Data by Artificial Neural Networks Approach", Applied Thermal Engineering, vol:27 pp: 1096-1104,2007.

[11] Chen, S., Mao, J,Chen,F., Hou,P.,Li,Y., "Development of ANN Model for Depth Prediction of Vertical Ground Heat Exchanger", International Journal of Heat and Mass Transfer, vol:117, pp: 617-626, 2018.

[12]Shojaeefard,M.H.Zare,J.,Tabatabaei,A.,Mohammadbe igi, H., "Evaluating Different Types of Artificial Neural Network Structures for Performance Prediction of Compact Heat Exchanger", Neural Computing \& Application, vol:28, pp: 3953-3965,2018.

[13] Ayli, E. Bayer,O. Aradag, S., "Experimental Investigation and CFD analysis of Rectangular Profile FINS in square channel for Forced Convection Regimes", International Journal of Thermal Sciences, vol:109, 279290,2016.

[14] Ayli,E., Kiyici,.F., Bayer,O.,Aradag, S., "Experimental investigation of heat transfer and pressure drop over rectangular profile fins placed in a square channel", Convective Heat and Mass Transfer (CONV 2014), June 2014

[15] Coleman, H.W., Steele, W.G., Experimntal and Uncertainity Analysis for Engineers, John Wiley\&Sons, New York, 1989.

[16] Munson, B.R., Young, D.F., Okiishi, T.H., "Fundementals of Fluid Mechanics", John Wiley\&Sons, USA,2006.

[17] Chatterjee, D., Biswas,G.,Amiroudine,S., "Numerical investigation of forced convection heat transfer in unsteady flow past a row of square cylinders", International Journal of Heat and Fluid Flow, vol:30, pp: 1114-1128,2009.

[18] Elmas, C.., "Yapay Sinir Ağları (Kuram, Mimari, Eğitim, Uygulama)”,„Seçkin Yayıncılık, Türkiye, 2003.

[19] Turk,C., "Yapay Sinir Ağları Yardımıyla Isı Değiştirgeci Modellemesi", MSc Thesis, TOBB University of Mechanical Engineering, Ankara, Turkey, 2013.

[20] Gang, W.J.,Wang,J.B. "Predictive ANN Models of Ground Heat Exchanger fort he Control of Hybrid Ground Source Heat Pump Systems," Applied Energy, vol:112, pp:1146-1153,2013.

[21] Beale, M.H., Hagan, M.T., Demuth, H.B., " Neural Network Toolbox, User's Guide", Mathworks, 2018.

[22] Sen, M., Yang, K.T., "Application of Artificial Neural Networks and Genetic Algortihms in Thermal Engineering", The CRC Handbook of Thermal Engineering, USA, 2000. 